\title{
Pengaruh Konseling Kognitif Perilaku dengan Teknik Restrukturisasi Kognitif terhadap Harga Diri Peserta Didik Kelas VIII Di MTs N 2 Bandar Lampung
}

\author{
Rika Damayanti, Puti Ami Nurjannah
}

\author{
Dosen Fakultas Tarbiyah dan Keguruan, IAIN Raden Intan Lampung
}

Diterima: 12 Mei 2016. Disetujui: 15 Juli 2016. Dipublikasikan: Nopember 2016

\begin{abstract}
Abstrak: Harga diri sebagai hasil evaluasi (kognisi) individu terhadap dirinya sendiri yang mempengaruhi emosi (afeksi) sehingga menampilkan perilaku menerima serta menunjukkan seberapa besar individu percaya pada dirinya bahwa dirinya berharga. Individu yang memiliki harga diri rendah biasanya cenderung kurang percaya diri, karena ia meremehkan bakatnya sendiri dan merasa tidak ada yang menghargainnya. Berdasarkan hasil observasi, wawancara dan penyebaran kuesioner harga diri yang peneliti lakukan di sekolah didapatkan peserta didik yang memiliki harga diri rendah seperti menghindari situasi yang mencetuskan kecemasan, kurang percaya diri dan menunjukkan jangkauan emosi yang sempit. Dari permasalahan tersebut peneliti mencoba menerapkan layanan konseling kognitif perilaku dengan teknik restrukturisasi terhadap peserta didik yang memiliki harga diri rendah. Tujuan dari penelitian ini yaitu untuk mengetahui pengaruh konseling kognitif perilaku dengan teknik restrukturisasi kognitif terhadap harga diri peserta didik kelas VIII di MTs N 2 Bandar Lampung Tahun Pelajaran 2016/2017. Jenis penelitian ini adalah kuantitatif dengan menggunakan preeksperimental designs dengan desain penelitian one-group pretest-posttest design. Subyek penelitian ini adalah peserta didik kelas VIII di MTs N 2 Bandar Lampung yang masuk dalam kriteria harga diri rendah. Kemudian didapatkan 12 sampel dengan menggunakan teknik sampling jenuh untuk menangani peserta didik tersebut. Hasil rata-rata skor harga diri sebelum mengikuti layanan konseling kognitif perilaku teknik restrukturisasi kognitif adalah 44,8 dan setelah mengikuti layanan konseling kognitif perilaku dengan teknik restrukturisasi kognitif meningkat menjadi 65,8. Dari hasil uji-t dengan derajat kebebasan df $=11$ dengan taraf signifikan $\alpha=0.05$ sebesar 1.796. karena thitung < dari tabel $(-13.472<1.796)$, maka Ho ditolak dan Ha diterima yang berarti ada pengharuh penerapan layanan konseling kognitif perilaku dengan teknik restrukturisasi kognitif terhadap harga diri peserta didik kelas VIII di MTs N 2 Bandar Lampung. Saran yang diajukan peneliti yaitu kepada guru bimbingan konseling diharapkan agar dapat memprogramkan dan melatih peserta didik dengan pelaksanaan layanan bimbingan konseling untuk mengatasi permasalahan peserta didik, terutama pada peserta didik yang memiliki penilaian diri negatif.
\end{abstract}

Kata Kunci: Konseling Kognitif Perilaku, Teknik Restrukturisasi Kognitif, Harga Diri

\section{Pendahuluan}

Peserta didik dengan harga diri tinggi akan menunjukkan inisiatif yang lebih besar, tetapi hal ini dapat menyebabkan akibat positif dan juga negatif. Peserta didik dengan harga diri tinggi akan rentan terhadap perilaku prososial ataupun antisosial. Sebagai contoh, mereka akan lebih mungkin dibandingkan dengan individu dengan harga diri harga diri rendah untuk membela temannya yang menjadi korban bullying, tetapi mereka juga akan lebih mungkin mengalami bullying.

Peserta didik yang memiliki harga diri tinggi, akan berbeda dengan peserta didik yang memiliki harga diri rendah. Clemes \& Bean, memberikan gambaran mengenai harga diri diantaranya:

Karakteristik harga diri tinggi;

1. merasa bangga akan prestasinya;

2. bertindak mandiri;

3. mudah menerima tanggung jawab;

4. mentolerir frustasi dengan baik;

5. menanggapi tantangan baru dengan antusias;

6. merasa sanggup mempengaruhi orang lain;

7. dan menunjukkan jangkauan perasaan dan emosi yang luas. 
Karakteristik harga diri rendah ;

1. menghindari situasi yang dapat mencetuskan kecemasan;

2. meremehkan bakatnya sendiri;

3. merasa bahwa orang lain tidak menghargainya;

4. menyalahkan orang lain atas kelemahan dirinya sendiri;

5. mudah dipengaruhi oleh orang lain;

6. mersikap defensif dan mudah frustasi;

7. merasa tidak berdaya;

8. dan menunjukkan jangkauan perasaan dan emosi yang sempit.

Peserta didik yang mempunyai penghargaan diri yang rendah akan pasif dan memendam bakat yang ia punya. Mereka beranggapan bahwa dirinya bukan apa-apa dan tidak mampu meraih prestasi. Peserta didik yang memiliki harga diri rendah juga akan menggisolasi diri dan sudah tidak lagi fokus pada tugasnya sebagai pelajar. Pada akhirnya prestasi belajarnya akan rendah dan pergaulan dengan teman sebaya akan renggang.

Hasil survey awal yang diperoleh melalui wawancara dengan guru BK mengenai masalah harga diri rendah yang dialami peserta didik di MTs Negeri 2 Bandar Lampung, diperoleh keterangan tentang upaya dalam meningkatkan harga diri peserta didik yaitu:

"Sejauh ini saya sebagai guru BK di sekolah sudah pernah melakukan upaya dalam meningkatkan harga diri siswa dengan melakukan konseling individu atau kelompok. Tetapi belum ada teknik khusus yang saya lakukan untuk meningkatkan harga diri siswa”.

Berdasarkan observasi yang dilakukan oleh peneliti bersama dengan guru BK di MTs N 2 Bandar lampung, diperoleh data peserta didik yang mengalami harga diri rendah yang sesuai dengan karakteristik seperti dalam tabel berikut ini:

Permasalahan harga diri rendah yang dialami oleh peserta didik, diperlukan upaya dari guru bimbingan konseling untuk memberikan bantuan terhadap peserta didik yang memiliki harga diri rendah. Bantuan dapat dilakukan melalui layanan responsif, karena layanan responsif merupakan pemberian bantuan kepada peserta didik yang menghadapi kebutuhan dan masalah yang memerlukan pertolongan dengan segera. Apabila peserta didik tidak segera diberi bantuan, dikhawatirkan akan memunculkan permasalahan yang lebih kronis seperti gangguan berhubungan dengan orang lain.

Layanan bimbingan konseling yang dapat digunakan untuk masalah harga diri rendah adalah konseling kognitif perilaku dengan teknik restrukturisasi kognitif. Layanan konseling yang mengarah pada harga diri yang efektif adalah restrukturisasi kognitif, yaitu teknik yang menghasilkan kebiasaan baru pada konseli dalam berpikir, merasa dan bertindak dengan cara mengidentifikasi kebiasaan- kebiasaan bermasalah, memberi label pada kebiasaan tersebut, dan menggantikan tanggapan/persepsi diri yang negatif/irasional menjadi lebih rasional/realistis.

Guindon mengatakan bahwa konseling kognitif perilaku adalah pendekatan yang paling umum yang digunakan untuk membantu masalah harga diri dan terbukti efektif dalam mengatasi masalah harga diri pada individu di seluruh rentan hidup. Sebagai contoh beberapa teknik dalam konseling kognitif perilaku, seperti: teknik relaksasi, teknik restrukturisasi kognitif, modelling, kemampuan belajar dan pelatihan intruksional diri, serta ketrampilan mengurangi kecemasan dapat meningkatkan harga diri pada tes akademik dalam belajar bagi siswa abnormal dan normal. Konseling kognitif perilaku adalah teori konseling yang dipopulerkan oleh Aaron T. Beck pada tahun 1960. Dalam awal konsep teori konseling dikenal dengan Cognitive Theraphy (CT) kemudian berkembang menjadi Cognitive Behavior Theraphy (CBT). Terapi kognitif adalah suatu pendekatan yang mengkombinasikan penggunaan teknik kognitif dan perilaku untuk membantu individu memodifikasi mood dan perilakunya dengan mengubah pikiran yang merusak diri. Premis dasar terapi kognitif adalah 
bahwa cara individu merasa atau berperilaku sebagian besar ditentukan oleh penilaian mereka terhadap peristiwa. Evaluasi ini diacu sebagai kognisi, dan terapi kognitif berfokus terutama pada pikiran yang merugikan diri yang berperan memuat mood menjadi jelek.

Aaron T. Beck mendefinisikan konseling kognitif sebagai pendekatan konseling yang dirancang untuk menyelesaikan permasalahan konseli, pada saat ini dengan cara melakukan restrukturisasi kognitif dari perilaku yang menyimpang, pikiran negatif dan perasaan yang tidak nyaman dapat membawa individu pada permasalahan psikologis yang lebih serius, seperti gangguan kecemasan bahkan depresi.

Mahoney \& Arnkoff mengungkapkan secara garis besar, teknik konseling kognitif perilaku diklasifikasikan ke dalam tiga bagian dengan fokus konseling yang berbeda-beda, yaitu :

a. Konseling ketrampilan coping, menekankan pada perkembangan ketrampilan yang dibentuk untuk membimbing konseli melakukan coping terhadap situasi-situasi yang dapat menimbulkan permasalahan.

b. Restrukturisasi kognitif, berfokus pada modifikasi kognitif konseli. Teknik restrukturisasi kognitif menekankan bahwa permasalahan yang dialami konseli merupakan konsekuensi dari pikiran yang negatif. Tujuan teknik restrukturisasi kognitif yaitu untuk membangun pola pokir yang lebih sesuai dan positif.

c. Terapi pemecahan masalah, merupakan kombinasi dari penerapan konseling ketrampilan coping dan restrukturisasi kognitif. Terapi ini menekankan pada pengembangan strategi umum dalam menghadapi ruang lingkup masalah individual yang luas, dan menekankan pentingnya kolaborasi aktif antara konseli dengan konselor dalam program konseling yang telah direncanakan dan disepakati.

Dari berbagai teknik yang ada, peneliti tertarik untuk menggunakan teknik restrukturisasi kognitif dari pendekatan konseling kognitif perilaku. Pemilihan ini didasari oleh latar belakang bahwa harga diri merupakan sebuah evaluasi diri, dan memiliki esensi yang terletak pada keyakinan dasar yang negatif mengenai dirinya. Keyakinan dasar ini melibatkan kognisi individu. Oleh karena itu peneliti memandang intervensi yang melibatkan fungsi kognitif individu seperti konseling kognitif perilaku lebih sesuai untuk meningkatkan harga diri. Tipe intervensi ini fokus pada identifikasi belief (keyakinan) yang disfungsional dan mengubahnya menjadi belief yang lebih realistis.

Santrock mengatakan bahwa ada empat cara yang dapat digunakan untuk meningkatkan harga diri remaja adalah sebagai berikut:

1. Mengidentifikasikan penyebab rendahnya harga diri dan bidang- bidang kompetensi yang penting bagi diri

2. Menyediakan dukungan emosional dan persetujuan social

3. Meningkatkan prestasi

4. Meningkatkan ketrampilan coping remaja

Berdasarkan gambaran dari latar belakang tersebut, penulis tertarik untuk melakukan penelitian dengan judul "Pengaruh Konseling Kognitif Perilaku dengan Teknik Restrukturisasi Kognitif Terhadap Harga Diri Peserta Didik Kelas VIII di MTs N 2 Bandar Lampung Tahun Ajaran 2016/2017"

Terapi kognitif adalah suatu pendekatan yang mengkombinasikan penggunaan teknik kognitif dan perilaku untuk membantu individu memodifikasi mood dan perilakunya dengan mengubah pikiran yang merusak diri. Terapis bertindak seperti pelatih, mengajari kliennya teknik dan strategi yang bisa ia gunakan untuk mengatasi masalah- masalahnya.

Asumsi dasar mengenai konseling kognitif perilaku adalah setiap perilaku individu merupakan hasil dari proses berpikir. Dalam konseling kognitif, individu diajak untuk menentang pikiran dan emosi yang salah dengan menampilkan bukti-bukti yang bertentangan 
dengan keyakinan individu mengenai masalah yang dihadapi. Aaron T. Beck juga mendefinisikan terapi kognitif sebagai terapi terstruktur jangka pendek yang menggunakan kerja sama aktif antara konseli dan konselor untuk mencapai tujuan terapeutik. Terapi ini berorientasi pada masalah sekarang dan pemecahannya. Terapi biasanya dilakukan atas dasar individual, walaupun metode kelompok juga digunakan.

Dari pernyataan diatas, dapat disimpulkan bahwa konseling kognitif perilaku merupakan pendekatan konseling yang mengkombinasikan penggunaan teknik kognitif dan perilaku untuk membantu menyelesaikan permasalahan konseli pada saat ini dengan cara melakukan restrukturisasi kognitif, yaitu mengajak konseli untuk menentang pikiran dan emosi yang salah dengan menampilkan bukti-bukti yang bertentangan dengan keyakinan konseli.

Tujuan dari konseling kognitif perilaku yaitu mengajak peserta didik untuk menentang pikiran dan emosi yang maladaptif dengan menampilkan bukti-bukti yang bertentangan dengan keyakinan peserta didik tentang masalah yang sedang dihadapi. Konseling kognitif berfungsi untuk memperbaiki pola pikir peserta didik menjadi lebih rasional dengan mengubah pikiranpikiran negatif tentang diri sendiri dan situasi-situasi di luar diri menjadi pikiran-pikiran yang positif. Setelah peserta didik memiliki pemikiran yang positif diharapkan dapat mengaplikasikannya ke dalam perilaku sehari-hari sebagai perilaku yang konstruktif dan positif.

Beck mengatakan, tujuan terapi kognitif adalah agar klien belajar menjadi terapis bagi dirinya, termasuk mengajarinya untuk:

1. Memonitor pikiran otomatis negatifnya

2. Mengenali hubungan antara kognisi, afek, dan perilaku.

3. Memeriksa dan menguji realitas bukti-bukti yang mendukung dan berlawanan dengan pikiran otomatis yang terdistorsi

4. Menggantikan kognisi- kognisi terbias denganinterpretasi-interpretasi yang realistis

5. Belajar mengidentifikasi dan mengubah keyakinan yang mempredisposisikannya untuk mendistorsi pengalamannya.

Murk mendefinisikan Restrukturisasi Kognitif, yaitu teknik yang menghasilkan kebiasaan baru pada konseli dalam berfikir, merasa, bertindak dengan cara mengidentifikasi kebiasaan bermasalah, memberi label pada kebiasaan tersebut, dan menggantikan tanggapan/perspsi diri yang negatif/irasional menjadi lebih rasional/relistis. Cognitive Restructuring memusatkan perhatian pada upaya mengidentifikasi dan mengubah pikiranpikiran atau pernyataan diri negatif dan keyakinan-keyakinan konseli yang tidak rasional. CR menggunakan asumsi bahwa respons-respons perilaku dan emosional yang tidak adaptif dipengaruhi oleh keyakinan, sikap, dan persepsi (kognisi) konseli

Konseling dengan menggunakan teknik restrukturisasi kognitif akan diarahkan pada perbaikan fungsi berfikir, merasa dan bertindak dengan menekankan otak sebagai pusat penganalisa, pengambil keputusan, bertanya, dan bertindak dan memutuskan kembali. Kesalahan berpikir yang biasanya bersifat tidak rasional menimbulkan pernyataan diri individu yang negatif. Rendahnya harga diri siswa dipengaruhi oleh irasionalitas, kebutaan terhadap realitas, pola pikir yang kaku, ketakutan pada hal baru dan persepsi pemikiran yang salah akan kondisi dirinya. Peneliti tertarik untuk menggunakan teknik restrukturisasi kognitif dari pendekatan konseling kognitif perilaku. Pemilihan ini didasari oleh latar belakang bahwa harga diri merupakan sebuah evaluasi diri, dan memiliki esensi yang terletak pada keyakinan dasar yang negatif mengenai dirinya. Keyakinan dasar ini melibatkan kognisi individu. Oleh karena itu peneliti memandang intervensi yang melibatkan fungsi kognitif individu seperti konseling kognitif perilaku lebih sesuai untuk meningkatkan harga diri. Tipe intervensi ini fokus pada identifikasi belief (keyakinan) yang disfungsional dan mengubahnya menjadi belief yang lebih realistis. 
Tujuan dari implementasi teknik restrukturisasi kognitif yaitu untuk membangun pola pikir yang lebih adaptif atau sesuai. Menurut Connolly, restrukturisasi kognitif membantu konseli untuk belajar berpikir secara berbeda, untuk mengubah pemikiran yang salah, mendasar dan menggantikannya dengan pemikiran yang lebih rasional, realistis, dan positif. Kesalahan berpikir diekspresikan melalui pernyataan diri yang negatif. Pernyataan diri yang negatif mengindikasikan adanya pikiran, pandangan dan keyakinan yang irasional.

Proses konseling yang didasarkan pada restrukturisasi kognitif diharapkan dapat memberikan pemahaman kepada konseli atas pemikiran yang irasional, emosi dan pola perilaku, harapan konseling kognitif perilaku yaitu munculnya restrukturisasi kognitif dari pemikiran yang irasional dan sistem kepercayaan yang menyimpang untuk membawa perubahan emosi dan perilaku ke arah yang lebih baik.

Murk mendifinisikan harga diri sebagai hasil evaluasi (kognisi) individu terhadap dirinya sendiri yang mempengaruhi emosi (afeksi) sehingga menampilkan perilaku menerima serta menunjukkan seberapa besar individu percaya pada dirinya bahwa dirinya berharga Santrock menyatakan harga diri sering disebut juga sebagai martabat diri (self worth) atau gambaran diri (self image) adalah suatu dimensi global dari diri. Sebagai contoh, seorang remaja mungkin menangkap bahwa ia tidak hanya sebagai seorang pribadi, namun juga seorang pribadi yang baik. Singkatnya, harga diri merujuk pada evaluasi diri yang bersifat global.

Pendapat lainnya mendefinisikan harga diri sebagai suatu kemampuan seseorang untuk dapat melakukan penghargaan terhadap diri sendiri. Kemampuan menghargai diri tidak dapat dilepaskan dengan kemampuan untuk menerima diri sendiri. Bila individu sudah mampu menerima diri, maka ia akan dapat menghargai dirinya dengan baik. Kemampuan untuk dapat menghargai terhadap diri sendiri sangat tergantung pada kemampuan seseorang untuk memandang, menganalisa, mengevaluasi dan menilai keberadaan dirinya sendiri.

Dapat disimpulkan bahwa harga diri adalah penilaian seseorang terhadap diri yang menunjukkan sejauh mana individu menyukai dirinya sebagai individu yang mampu, penting, dan berharga. Harga diri individu bisa menjadi positif/tinggi atau negatif/rendah, tergantung bagaimana individu tersebut menilai tentang dirinya. Penilaian individu tersebut dapat terlihat melalui sikap dan perilakunya.

Harga diri tempaknya berfluktuasi sepanjang masa hidup. Para peneliti masih belum sepakat sejauh mana harga diri berubah seiring bertambahnya usia. Penelitian terkahir menunjukkan bahwa harga diri akan tinggi pada masa kanak- kanak, menurun pada masa remaja, meningkat lagi pada masa dewasa sampai dewasa akhir, dimana harga diri kembali menurun. Beberapa peneliti berpendapat bahwa meskipun harga diri menurun pada masa remaja, penurunan ini sebenarnya hanya sedikit. Pada masa remaja, penurunan harga diri lebih banyak terjadi pada remaja perempuan dibandingkan dengan remaja laki- laki. Penurunan harga diri didorong oleh citra tubuh yang negatif selama perubahan di masa puber dibandingkan dengan remaja laki- laki. Penjelasan yang lain berfokus pada ketertarikan yang lebih dari remaja perempuan untuk terlibat dalam hubungan sosial, sehingga menyebabkan kemungkinan kegagalan yang lebih pada perempuan.

Para peneliti menemukan bahwa harga diri seringkali mengalami masa transisi dari sekolah dasar menuju sekolah menengah. Sesungguhnya, selama dan setelah mengalami transisi hidup, harga diri individu seringkali mengalami penurunan. Penurunan harga diri ini dapat berlangsung selama transisi dari awal atau pertengahan hingga akhir sekolah menegah atas, dan dari sekolah menengah atas hingga kampus. 


\section{Metode Penelitian}

Jenis penelitian yang penulis gunakan dalam penelitian ini adalah penelitian eksperimen. Metode penelitian eksperimen merupakan metode penelitian yang digunakan untuk mencari pengaruh treatment (perlakuan) tertentu. Pada penelitian eksperimen dilakukan peneliti untuk mengetahui bagaimana pengaruh antara treatment yang diberikan guna meningkatkan harga diri peserta didik. Penelitian eksperimen digunakan peneliti sesuai dengan tujuan dan permasalahan yaitu Pengaruh Konseling Kognitif Perilaku dengan Teknik Restrrukturisasi Kognitif Terhadap Harga Diri Peserta Didik Kelas VIII di MTs N 2 Bandar Lampung Tahun Ajaran 2016/2017.

\section{Hasil Dan Pembahasan}

Sebelum pemberian treatment yaitu layanan konseling kelompok dilaksanakan, ada beberapa hal yang perlu dipersiapkan peneliti dalam penelitian ini. Adapun tahap- tahap dalam penelitian yang dilakukan antara lain:

1. Mencatat daftar nama peserta didik kelas VIII MTs N 2 Bandar Lampung

2. Penentuan sample penelitian, berdasarkan penyebaran kuesioner skala harga diri pada kelas VIII kemudian diperoleh 12 peserta didik dengan kriteria rendah.

3. Meminta persetujuan pada peserta didik untuk dijadiakan sample dalam penelitian.

4. Pelaksanaan konseling kelompok dilaksanakan bersama 12 peserta didik dengan data sebagai berikut:

5.

Tabel 1. Peserta Didik Yang Mengikuti Konseling Kelompok

\begin{tabular}{|c|c|c|}
\hline No & Kode Nama & Kelas \\
\hline 1 & AY & $8 \mathrm{~J}$ \\
\hline 2 & MDI & $8 \mathrm{~F}$ \\
\hline 3 & MI & $8 \mathrm{G}$ \\
\hline 4 & AR & $8 \mathrm{G}$ \\
\hline 5 & AJ & $8 \mathrm{G}$ \\
\hline 6 & AYP & $8 \mathrm{~F}$ \\
\hline 7 & MR & $8 \mathrm{H}$ \\
\hline 8 & TM & $8 \mathrm{I}$ \\
\hline 9 & ANP & $8 \mathrm{I}$ \\
\hline 10 & IFI & $8 \mathrm{G}$ \\
\hline 11 & MJP & $8 \mathrm{~J}$ \\
\hline 12 & HRN & $8 \mathrm{~J}$ \\
\hline
\end{tabular}

6. Menjelaskan kepada subjek penelitian mengenai prosedur pelaksanaan konseling kelonpok layanan dan menyepakati waktu pertemuan.

7. Pelaksanaan konseling kelompok dilakukan di MTs N 2 Bandar Lampung, pertemuan dilakukan sebanyak 6 kali pertemuan, yang dilaksanakan di ruang bk pada pukul 09.00 WIB dengan jadwal pertemuan sebagai berikut: 
Tabel 2. Jadwal Pemberian Perlakuan Konseling Kelompok

\begin{tabular}{|c|c|l|}
\hline No & Tanggal & \multicolumn{1}{|c|}{ Kegiatan yang dilaksanakan } \\
\hline 1 & $28-9-2016$ & $\begin{array}{l}\text { Pretest dan Pertemuan Pertama } \\
\text { materi : konseling kelompok dan harga diri }\end{array}$ \\
\hline 2 & $29-9-2016$ & $\begin{array}{l}\text { Pertemuan Kedua } \\
\text { materi : pandangan negatif tentang diri, dan berfikir positif }\end{array}$ \\
\hline 3 & $5-10-2016$ & $\begin{array}{l}\text { Pertemuan Ketiga } \\
\text { materi : kekuatan sugesti diri }\end{array}$ \\
\hline 4 & $6-10-2016$ & $\begin{array}{l}\text { Pertemuan Keempat } \\
\text { materi sukses berfikir positif }\end{array}$ \\
\hline 5 & $7-10-2016$ & $\begin{array}{l}\text { Pertemuan Kelima } \\
\text { materi : evaluasi diri setiap waktu }\end{array}$ \\
\hline 6 & $10-10-2016$ & $\begin{array}{l}\text { Pertemuan Keenam } \\
\text { materi : evaluasi kegiatan dan posttest }\end{array}$ \\
\hline
\end{tabular}

Berdasarkan tabel tersebut pelaksanaan konseling kognitif perilaku dengan teknik restrukturisasi kognitif dilakukan sebanyak 6 kali pertemuan beserta pretest dan posttest dengan rincian kegiatan sebagai berikut :

1. Pertemuan Pertama

Pertemuan pertama dilaksanakan di ruang bk, pada pukul 09.00 WIB. Kegiatan konseling kelompok ini diawali dengan mengucapkan salam pembuka kepada anggota kelompok. Pemimpin kelompok memperkenalkan diri, dan menjelaskan maksud dan tujuan dari kegiatan konseling kelompok ini serta menjelaskan tatacara pelaksanaan, asas-asas dalam konseling kelompok dan menyampaikan kesepakatan waktu. Anggota kelompok diberikan kesempatan untuk bertanya kepada pemimpin kelompok, kemudian dilanjutnya perkenalan antar anggota kelompok.

Pada tahap peralihan, pemimpin kelompok menjelaskan kembali maksud dan tujuan dari kegiatan konseling kelompok dilakukan. Selanjutnya pemimpin kelompok menumbuhkan sikap kebersamaan diantara angota kelompok dengan mengadakan permainan. Pemimpin kelompok mengadakan permainan untuk membangun suasana hangat diantara anggota kelompok. Selanjutnya, pada tahap kegiatan pemimpin kelompok menjelaskan peran anggota kelompok agar aktif berpendapat dan berani dalam mengungkapkan segala permasalahan yang sedang dihadapinya. Pemimpin kelompok menjelaskan mengenai pengertian konseling kelompok, menjelaskan asas-asas dalam konseling kelompok, menjelaskan tentang harga diri dan meminta peserta didik untuk mengungkapkan masalahnya. Anggota kelompok diminta untuk mengisi form "saya itu..." dengan tujuan anggota kelompok dapat mengenali dan memahami tentang dirinya baik kekurangan dan kelebihan yang anggota kelompok miliki. Ketika kegiatan berakhir, pemimpin kelompok memberikan kesimpulan dari pertemuan yang dilakukan dan memberikan kesempatan kepada anggota kelompok untuk bertanya. Selanjutnya pemimpin kelompok menanyakan pesan dan kesan kepada anggota kelompok setelah mengikuti kegiatan ini dan menyepakati waktu untuk pertemuan selanjutnya. Kemudian kegiatan konseling kelompok diakhiri dengan membaca doa dan salam penutup.

2. Pertemuan Kedua

Pertemuan kedua dilaksanakan pada pukul 09.00 di ruang bk. Pemimpin kelompok segera membuka pertemuan dengan mengucapkan salam dan berdoa. Kemudian pemimpin kelompok memberikan permainan konsentrasi, supaya anggota lebih berkonsentrasi dalam mengikuti kegiatan ini. Selanjutnya menjelaskan topik yang akan dibahas pada 
kegiatan pertemuan kedua ini yaitu pandangan negatif tentang diri. Pemimpin kelompok menjelaskan perbedaan pemikiran negatif dan positif, kemudian menjelaskan pentingnya berfikir positif. Dalam tahap ini, seluruh anggota kelompok diminta untuk berperan aktif dan terbuka mengemukakan apa yang dirasakan, dipikirkan dan dialaminya. Selanjutnya memilih masalah yang sering muncul sesuai kesepakatan anggota kelompok. Anggota kelompok memilih asumsi/pemikiran negatif mana yang ingin diubah/diganti. Pemimpin kelompok mempersilahkan untuk menuliskan masalahnya mengenai pandangan negatif tentang dirinya dengan mengisi form "catatan pikiran I". Kemudian mempersilahkan salah satu anggota kelompok untuk mengemukakan apa yang sudah dituliskan di form tersebut. Kemudian pemimpin kelompok dan anggota kelompok lainnya memberikan umpan balik/respon terhadap masalah yang dibahas. Pemimpin kelompok memberikan tugas rumah berupa "catatan pikiran I" kepada anggota kelompok. Pemimpin kelompok menginformasikan bahwa kegiatan konseling akan segera berakhir. Kemudian menanyakan pesan dan kesan kepada anggota kelompok pada pertemuan yang kedua ini. Pertemuan diakhiri dengan doa dan salam penutup.

3. Pertemuan Ketiga

Pertemuan ketiga dilaksanakan di ruang bk pukul 09.00 WIB, dan diawali dengan salam pembuka dan berdoa oleh pemimpin kelompok. Pemimpin menanyakan kabar dan memberikan semangat pada anggota kelompok. Pemimpin kelompok mengulas kembali kegiatan konseling kelompok pertemuan sebelumnya, membahas tugas rumah yang diberikan pada pertemuan sebelumnya. Selanjutnya, pemimpin kelompok menjelaskan mengenai sugesti diri. Setelah itu, pemimpin kelompok meminta anggota kelompok untuk mengisi "form "catatan pikiran II" untuk membantu membatah keyakinan yang irasional yang sebelumnya sudah dituliskan pada form "catatan pikiran I" dengan memberikan pertanyaan sokratik, seperti: Apa anda punya bukti yang mendukung pemikiran anda tersebut?". Kemudian pada colom E, anggota kelompok menuliskan cara pandang/pemikiran alternatif yang lebih rasional terhadap situasi yang dihadapinya. Meminta anggota kelompok membaca pikiran positif/rasionalnya secara berulang dan mengaplikasikannya dalam kehidupan sehari-hari. Setelah itu seluruh anggota kelompok mempraktikkannya. Pemimpin kelompok memberikan tugas rumah berupa catatan pikiran I dan II untuk melatih anggota kelompok terbiasa berfikir positif. Pemimpin kelompok menyimpulkan dari kegiatan yang telah berlangsung, dan meminta anggota kelompok untuk memberikan kesannya pada pertemuan ini. Kegiatan konseling kelompok ditutup dengan doa dan salam penutup.

4. Pertemuan keempat

Pertemuan selanjutnya dilaksanakan di ruang bk pada pukul 09.00 WIB. Kegiatan konseling kelompok dibuka dengan salam pembuka dan doa. Pemimpin kelompok berterimakasih kepada seluruh anggota kelompok karena bersedia mengikuti layanan konseling kelompok ini. Setelah itu masuk ke kegiatan inti dengan membahas pertemuan selanjutnya, dan menanyakan tentang tugas rumah yang diberikan. Menanyakan kepada anggota kelompok, adakah kesulitan yang dihadapi dalam menerapkan teknik rekam pikiran ini.

Kemudian menjelaskan kepada anggota kelompok mengenai topik yang akan dibahas pada pertemuan ini yaitu evaluasi diri setiap waktu. Pada pertemuan ini, anggota kelompok diajarkan untuk mengevaluasi prestasi akademisnya dengan melihat perkembangan nilai dan perkembangan spiritualnya. Kemudian anggota kelompok diminta untuk membuka lembar "catatan pikiran I dan II" kemudian membacakan kembali kolom bagian E yaitu pemikiran rasional anggota kelompok. Agar anggota kelompok bisa menerapkan/mengaplikasikannya dalam sikapnya. Pemimpin kelompok mempersilahkan kepada anggota kelompok untuk bertanya. Kemudian membahasnya secara bersama. 
Setelah itu pemimpin kelompok mengambil kesimpulan dari materi yang sudah dibahas dan anggota kelompok mengungkapkan kesannya setalah mengikuti kegiatan pada pertemuan keempat ini. Kegiatan konseling kelompok diakhiri dengan doa dan salam penutup.

5. Pertemuan kelima

Kegiatan konseling kelompok di laksanakan di ruang bk pada pukul 09.00 WIB. Pada pertemuan selanjutnya, pemimpin kelompok membuka kegiatan konseling kelompok dengan salam pembuka dan doa. Kemudian pemimpin kelompok mengulas kembali kegiatan pada pertemuan sebelumnya. Selanjutnya, pemimpin kelompok menjelaskan materi yang dibahas pada pertemuan kali ini, yaitu sukses dengan berfikir positif. Pemimpin kelompok memberikan tips berfikir positif. Kemudian meminta konseli untuk mengisi form "karakteristik saya..." dan "jurnal positif". Kemudian membahas materi, dan form yang sudah diisi. Setelah itu pemimpin kelompok memberitahukan anggota kelompok bahwa kegiatn konseling akan segera berakhir. Pemimpin kelompok menutup konseling dengan doa dan salam penutup.

6. Pertemuan keenam

Pertemuan keenam dilaksanakan di ruang BK pada pukul 09.00 WIB. Pemimpin kelompok membuka kegiatan dengan salam pembuka dan doa. Setelah itu pemimpin kelompok menjelaskan bahwa ini adalah pertemuan terakhir. Pada pertemuan terakhir, pemimpin kelompok mengulas kembali dari pertemuan yang pertama sampai pertemuan terakhir. Kemudian seluruh anggota dan pemimpin kelompok mengevaluasi tugas rumah yang diberikan kepada anggota kelompok. Pemimpin kelompok memberikan penguatan positif, dan meyakinkan bahwa pikiran-pikiran negatif yang diyakini oleh anggota kelompok adalah tidak benar. Dan meminta kepada anggota kelompok untuk menerapkan apa yang dituliskan dalam jurnal positif dan catatan pikiran kolom E. Selanjutnya pemimpin kelompok meminta untuk mengisi kuesioner harga diri pada anggota kelompok. Setelah itu pemimpin kelompok mengucapkan terimakasih kepada anggota kelompok, dan anggota kelompok mengungkapkan kesan dan pesan anggota kelompok. Dan menutup kegiatan dengan membaca doa dan salam penutup.

7. Membandingkan nilai rata-rata peserta didik sebelum dan setelah mengikuti kegiatan layanan konseling kogniif perilaku dengan setting kelompok. Berdasarkan data yang diperoleh, maka dapat dideskripsikan hasil penelitian sebelum dilakukan perlakuan dan setelah diberikan perlakuan.

Pre-test dilakukan dengan tujuan untuk mengetahui gambaran kondisi awal harga diri peserta didik kelas VIII di MTs N 2 Bandar Lampung. Berikut dijelaskan, kondisi pre-test gambaran kondisi awal harga diri peserta didik: 
Tabel 3. Hasil Pre-test Harga Diri Peserta Didik

\begin{tabular}{|c|c|c|c|}
\hline No & Kode Nama & Hasil Pre-test & Kriteria \\
\hline 1 & AY & 44 & Rendah \\
\hline 2 & MDI & 43 & Rendah \\
\hline 3 & MI & 46 & Rendah \\
\hline 4 & AR & 46 & Rendah \\
\hline 5 & AI & 47 & Rendah \\
\hline 6 & AYP & 46 & Rendah \\
\hline 7 & MR & 46 & Rendah \\
\hline 8 & TM & 40 & Rendah \\
\hline 9 & ANP & 43 & Rendah \\
\hline 10 & IFI & 45 & Rendah \\
\hline 11 & MIP & 46 & Rendah \\
\hline 12 & HRN & 46 & Rendah \\
\hline
\end{tabular}

Tabel 4 Hasil Post-test Harga Diri PesertaDidik

\begin{tabular}{|c|c|c|c|}
\hline No & Kode Nama & Hasil Post- test & Kriteria \\
\hline 1 & AY & 73 & Sedang \\
\hline 2 & MDI & 60 & Sedang \\
\hline 3 & MI & 64 & Sedang \\
\hline 4 & AR & 69 & Sedang \\
\hline 5 & AI & 72 & Sedang \\
\hline 6 & AYP & 58 & Sedang \\
\hline 7 & MR & 70 & Sedang \\
\hline 8 & TM & 62 & Sedang \\
\hline 9 & ANP & 64 & Sedang \\
\hline 10 & IFI & 67 & Sedang \\
\hline 11 & MIP & 65 & Sedang \\
\hline 12 & HRN & 57 & Sedang \\
\hline
\end{tabular}

Berdasarkan tabel tersebut, setelah diberikan perlakuan konseling kognitif perilaku pada peserta didik kelas VIII yang memiliki masalah harga diri rendah di MTs N 2 Bandar Lampung sehingga menghasilkan perubahan berupa peningkatan harga diri peserta didik. Jadi dapat disimpulkan bahwa Konseling Kognitif Perilaku dapat meningkatkan harga diri peserta didik, peserta didik sudah mengalami perubahan yang lebih baik dari sebelum diberikan perlakuan Konseling Kognitif Perilaku.

Berdasarkan hasil analisis data, terlihat terdapat adanya peningkatan pada harga diri peserta didik kelas VIII di MTs N 2 Bandar Lampung. Dapat dilihat pada tabel dari hasil penelitian sebelum dan sesudah diberikannya layanan konseling kognitif perilaku teknik restrukturisasi kognitif. Selain itu dilakukan uji hipotesis menggunakan uji t paired sample ttest dan diketahui t adalah -13.472 mean - 20.25000,95\% confidence interval of the difference, lower $=-23.55842$ dan upper $=-16.94158$, kemudian thitung dibandingkan dengan ttabel $\mathrm{df}=$ 11 , dengan ketentuan thitung $<$ tabel $(-13.472<1.796)$ dikarenakan peneliti mengambil taraf signifikan $\alpha=0.05$ dengan nilai distribusi nilai satu arah untuk kriteria pengujian hipotesis yang peneliti ajukan, maka Ha diterima.Sedangkan perbandingan skor pretest 44,8 dan posttest 65.08 yang berarti terjadi peningkatan sebesar 20,2. Meningkatkan harga diri peserta didik melalui konseling kelompok dengan menggunakan pendekatan konseling kognitif perilaku dilakukan dengan beberapa tahap konseling dengan enam kali pertemuan. Menurut penelitian 
Anisah Fadhilah dalam skripsi yang berjudul Teknik Retrukturisasi Kognitif Untuk Meningkatkan Harga Diri Peserta Didik yang direncanakan untuk pemberian treatment akan dilaksanakan selama 6 sesi dengan waktu pelaksanaan 1x60 menit dan jadwal pelaksanaan konseling berdasarkan kesepakatan pemimpin kelompok dan anggota kelompok.

Dalam penelitian ini diterapkan layanan konseling kognitif perilaku dengan teknik restrukturisasi kognitif. Murk mendefinisikan restrukturisasi kognitif, yaitu teknik yang menghasilkan kebiasaan baru pada konseli dalam berfikir, merasa, bertindak dengan cara mengidentifikasi kebiasaan bermasalah, memberi label pada kebiasaan tersebut, dan menggantikan tanggapan/perspsi diri yang negatif/irasional menjadi lebih rasional/relistis. Peneliti tertarik untuk menggunakan teknik restrukturisasi kognitif dari pendekatan konseling kognitif perilaku. Pemilihan ini didasari oleh latar belakang bahwa harga diri merupakan sebuah evaluasi diri, dan memiliki esensi yang terletak pada keyakinan dasar yang negatif mengenai dirinya. Keyakinan dasar ini melibatkan kognisi individu. Oleh karena itu peneliti memandang intervensi yang melibatkan fungsi kognitif individu seperti konseling kognitif perilaku lebih sesuai untuk meningkatkan harga diri. Tipe intervensi ini fokus pada identifikasi belief (keyakinan) yang disfungsional dan mengubahnya menjadi belief yang lebih realistis.

Setelah diberikan perlakuan sebanyak 6 kali pertemuan, peserta didik dapat memahami dan mengerti topik yang dibahas untuk itu peserta didik dapat mengaplikasikannya melalui sikap dan tindakannya dalam menilai dirinya secara positif. Secara indikator terjadi peningkatan harga diri setelah diadakan konseling kelompok dengan tektik restrukturisasi kogniif., yaitu :

a. Kognisi

Berdasarkan hasil penyebaran kuesioner harga diri yang terjadi pada indikator perasaan diterima terjadi peningkatan setelah dilakukan konseling kelompok, dapat dilihat dari nilai uji t paired samples t-test 2.24537 meningkat menjadi 2.11233. peserta didik mampu mentoleransi rasa takut dan amarahnya.

b. Emosi

c. erdasarkan hasil penyebaran kuesioner harga diri yang terjadi pada indikator perasaan diterima terjadi peningkatan setelah dilakukan konseling kelompok, dapat dilihat dari nilai uji t paired samples t-test 1.50302 meningkat menjadi 2.05319. Peserta didik sudah merasa dihargai oleh orang lain.

d. Perilaku

Berdasarkan hasil penyebaran kuesioner harga diri yang terjadi pada indikator perasaan diterima terjadi peningkatan setelah dilakukan konseling kelompok, dapat dilihat dari nilai uji t paired samples t-test 1.74620 meningkat menjadi 2.03417. Peserta didik mampu mengekspresikan perasaan emosinya seperti tertawa, menangis dan sebagainya. Hal ini senada dengan pendapat Hence bahwa seseorang dengan harga diri tinggi dapat mengekspresikan perasaannya dengan baik.

\section{Simpulan dan Saran}

Berdasarkan hasil penelitian teknik restrukturisasi kognitif dalam menangani harga diri yang rendah pada peserta didik kelas VIII di MTs n 2 Bandar Lampung Tahun Pelajaran 2016/2017 dapat disimpulkan bahwa hasil perhitungan rata- rata skor harga diri sebelum mean pretest mengikuti layanan konseling kognitif perilaku teknik restrukturisasi kognitif adalah 44,8 dan setelah mean posttest mengikuti layanan konseling kognitif perilaku dengan teknik restrukturisasi kognitif meningkat menjadi 65,8. Dari hasil uji-t menggunakan program SPSS versi 16 , bahwa t adalah -13.472 , mean $-20.25000,95 \%$ confidence interval of the difference, lower $=-23.55842$ dan upper $=-16.94158$, Kemudian thitung dibandingkan dengan ttabel $\mathrm{df}$ $=11$, dengan ketentuan thitung < dari ttabel $(-13.472<1.796)$, dengan demikian peserta didik yang dikategorikan rendah terdapat perubahan setelah diberikan layanan konseling kognitif 
perilaku dengan teknik restrukturisasi kognitif. Dilihat dari ketentuan thitung $<$ ttabel, hasil perhitungan lebih besar thitung < ttabel, dengan demikian dapat disimpulkan bahwa hipotesis nihil (Ho) di tolak dan hipotesis kerja (Ha) yang berbunyi layanan Konseling Kognitif Perilaku dengan Teknik Restrukturisasi Kognitif berpengaruh Terhadap Harga Diri Peserta Didik Kelas VIII di MTs n 2 Bandar Lampung Tahun Ajaran 2016/2017 diterima. Kesimpulan dalam penelitian ini yaitu terdapat peningkatan skor dengan demikian peserta didik yang memiliki harga diri rendah mengalami perubahan setelah melaksanakan layanan konseling kognitif perilaku dengan teknik restrukturisasi kognitif melalui konseling kelompok pada peserta didik kelas VIII MTs N 2 Bandar Lampung Tahun Pelajaran 2015/2016. Hal ini ditunjukkan dari perubahan perilaku pada peserta didik dalam setiap pertemuan pada kegiatan konseling kelompok dan perilaku peserta didik dalam kegiatan sekolah sehari-hari ditunjukkan dengan peserta didik mampu mentolerasi rasa takut atau amarahnya, peserta didik sudah merasa dirinya berharga dan dihargai oleh orang lain, dan mampu mengekspresikan perasaan emosinya.

Berdasarkan hasil penelitian ini dibuktikan dengan adanya perubahan peserta didik yang dikategorikan harga diri rendah setelah diberikan layanan konseling kelompok dengan teknik restrukturisasi kognitif, maka ada beberapa saran yang dapat digunakan sebagai bahan pertimbangan yaitu: 1 . Peserta didik diharapkan dapat mengevaluasi/menilai diri secara positif, mampu menunjukkan penerimaan terhadap apapun keadaan dirinya dan orang lain sehingga timbul rasa saling menghargai. 2. Guru bimbingan dan konseling diharapkan agar dapat memprogramkan dan melatih peserta didik dengan melaksanakan pelayanan bimbingan dan konseling sesuai dengan kurikulum yaitu untuk mengatasi permasalahan- permasalahan yang terjadi pada peserta didik, terutama pada peserta didik yang dikategorikan memiliki harga diri rendah. 3. Untuk peneliti lebih lanjut, diharapkan dapat melakukan penelitian yang lebih luas dan komprehensif mengenai teknik restrukturisasi kognitif dalam menangani peserta didik dengan harga diri rendah dan perlu diadakannya layanan bimbingan dan konseling individu maupun kelompok untuk mengetahui masalah-masalah terkait harga diri (penilaian diri) pada peserta didik secara lebih mendalam.

\section{Daftar Pustaka}

Hadi Sutrisno, Metodologi Research, (Yogyakarta, Andi Offset, 1988).

Haryanthi Putu Suta Luh \& Tresniasari Nia, Efektifitas Metode Terapi Ego State Dalam Mengatasi Kecemasan Di Depan Publik Pada Mahasiswa Fakultas Psikologi UIN Syarif Hidayatullah Jakarta (Online) Jurnal, (http://journal.unair.ac.idfilerPDFartikel\%204-14-1.pdf diakses pada tanggal26 Februari 2016 pukul 12.32 WIB.

Jayanti Tri, 2012, Mengurangi Perilaku Siswa tidak Tegas Melalui Pendekatan REBT dengan Teknik Assertive Training Univ. Negeri Semarang, (Online) Jurnal (http://journal.unnes.ac.idartikel_sjujbk309358.pdf diakses pada pukul 19.20 WIB 28 Januari 2016.

Kartono Kartini, Kamus Lengkap Psikologi, (Jakarta: Raja Grafindo Persada, 2004)

Khairani Makmun, Psikologi Konseling, (Yogyakarta, CV. Aswaja Persindo, 2014).

Mappiare Andi, Pengantar Konseling dan Psikoterapi edisi Kedua, (Jakarta; PT .Rahja Grafindo Persada, 2011).

Margono.S, Metodologi Penelitian Pendidikan, (Jakarta: PT Rineka Cipta, 2010).

Novalia, Muhamad Syazali, Olah Data Penelitian Pendidikan, Bandar Lampung, 2014 
Nurul Hidayah, Model Konseling Trait And Factor Terhadap Perencanaan Karir Pada Peserta Didik Kelas Vll Sekolah Manangah Pertama Negeri 28 Bandar Lampung Tahun Pelajaran 2013, Skripsi, (Bandar Lampung: Iain Raden Intan Lampung, 2014),

Prayitno Dan Amti, Erman, Dasar-Dasar Bimbingan dan Konseling. Jakarta, Pt. Rineka Cipta.2008

Purwati, Cicih. Meningkatkan Minat Studi Lanjut Ke Smk Melalui Layanan Informasi Karir Peserta Didik Kelas VIII SMP 2 Salem, Skripsi, Semarang, Universitas Negeri Semarang.

Arsyad, Azhar. Media Pembelajaran. Jakarta: PT Raja Grafindo Persada. 2015.

Gladding, Samuel T. The Creative Arts In Counseling. USA: American Counseling Associations.2011.

Hasanah, Nur. Pengaruh Bimbingan Kelompok Teknik Lingkaran (Round) Terhadap Percaya Diri Siswa Kelas VIII Di SMP Negeri 2 Gorontalo. (Skripsi Program Sarjana Pendidikan Universitas Negeri Gorontalo)

Illarezkiwanda, Dunia BK-Bimbingan dan Konseling. [on-line], tersedia di: http://illarezkiwanda.blogspot.co.id/ [3 Maret 2016]

Ivanne's Gallery, Peranan Percaya Diri Dalam Pembelajaran. [On-Line], tersedia di: http://vanneisblessing.blogspot.co.id/2012/02/peranan-percaya-diri-dalampembelajaran.html [31 Januari 2016]

John Creswell. Research Design Pendekatan Kualitatif, Kuantitatif, dan Mixed. Yogyakarta: Pustaka Pelajar. 2013.

Maharani, Laila. Konseling Puisi: Konseling Diri Melalui Media Puisi. Bandar Lampung: CV. Teams Barokah. 2014.

Maya, Citraan Dalam Puisi, [On-Line], tersedia di: https://kelasmayaku.wordpress.com/2011/02/09/citraan-dalam-puisi/ [21 Maret 2016]

Muhibbinsyah. Psikologi Pendidikan. Bandung: PT Remaja Rosdakarya. 2010.

Mustari, Mohamad. Nilai Karakter Refleksi Untuk Pendidikan. Jakarta: PT Raja Grafindo Persada. 2014.

Nursalim, Mochamad. Media Bimbingan dan Konseling. Jakarta: Unesa university press.2010.

Prayitno. Dasar-Dasar Bimbingan dan Konseling. Jakarta: Rineka Cipta. 2008.

Purwanti, septi rahayu. "mengatasi masalah kepercayaan diri siswa melalui layanan konseling kelompok pada siswa kelas VIII F SMP Negeri 2 Karangpucung kabupaten cilacap”. (Skripsi Program Sarjana Pendidikan Universitas Negeri Semarang, Semarang, 2013) 
